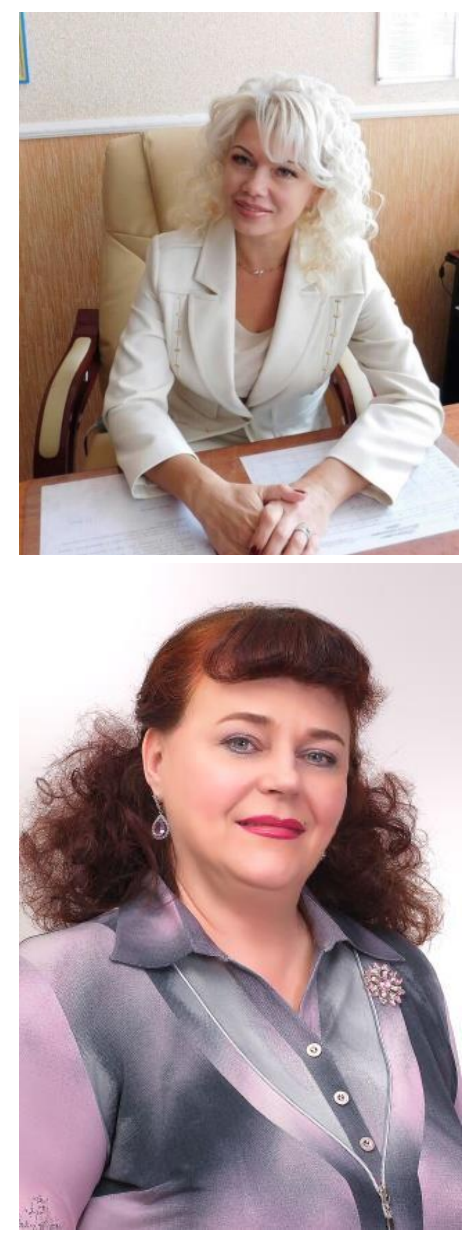

\title{
ПСИХОЛОГО-ПЕДАГОГІЧНІ НАПРЯМИ ОПТИМІЗАЦІЇ СОЩАЛІЗАЦІЇ ДІТЕЙ ІЗ ПСИХОФІЗИЧНИМИ ПОРУШЕННЯМИ В ПРОЦЕСІ ПРОФЕСІЙНӦ̈ ПІДГОТОВКИ
}

\author{
Олена Мамічева \\ доктор психологічних наук, професор, \\ декан факультету спеціальної освіти, \\ ДВНЗ «Донбаський державний педагогічний \\ університет», \\ м. Слов'янськ, Україна \\ ORCID ID 0000-0001-5299-7939 \\ lena_sk_74@ukr.net \\ Ірина Татьянчикова \\ доктор педагогічних наук, професор, \\ завідувачка кафедри спеціальної педагогіки та \\ інклюзії, \\ ДВНЗ «Донбаський державний педагогічний \\ університет», \\ м. Слов'янськ, Україна \\ ORCID ID 0000-0002-9526-9672 \\ i.tatyanchikova@gmail.com
}

Анотація. Статтю присвячено визначенню напрямів оптимізації соціалізації дітей із психофізичними порушеннями на стадії ранньої трудової підготовки в спеціальному навчальному закладі. Розкрито основні змістові лінії здійснення корекційно-розвивальної роботи на зазначеній стадії, а також основні протиріччя, які гальмують подальшу професійну соціалізацію учнів. Акцентовано увагу на необхідність посилення профорієнтаційної роботи в спеціальній загальноосвітній школі; визначено основні ії недоліки. Запропоновано напрями вдосконалення професійної підготовки учнів із психофізичними порушеннями. Професійне навчання розглянуто в контексті управління діяльністю школярів 3 оволодіння ними відповідними знаннями, уміннями й навичками, розвитку в них професійно важливих якостей. Розкрито основні ключові питання, які сприяють забезпеченню соціалізації учнів у процесі професійної підготовки в спеціальному навчальному закладі.

Ключові слова: соціалізація; діти з психофізичними порушеннями; стадії соціалізації; профорієнтаційна робота.

Постановка проблеми в загальному вигляді. У сучасних умовах розвитку суспільства суттєво загострюються питання підготовки дітей iз психофізичними порушеннями до самостійного життя, що потребує володіння ними не лише знаннями і навичками, які передбачено шкільною програмою, але 
й уміннями розв'язувати певні життєві проблеми, адаптуватися до складних умов сьогодення, адекватно орієнтуватися в соціумі. Реалізація зазначених завдань стає тягарем для дітей цієї категорії, бо більшість із них неспроможна адекватно реагувати на потреби суспільства, приймати його виклики, зазнає істотних труднощів при вступі до самостійного життя і трудової діяльності, недооцінює роль професійної підготовки в школі. Саме тому спеціальний навчальний заклад зобов'язаний підготувати учня до життєдіяльності, орієнтуючись на його індивідуальні можливості та перспективи розвитку. Водночас від успішності соціалізації залежить не лише самовідновлюваність суспільних відносин осіб із психофізичними порушеннями, але й комфортність їхньої життєдіяльності в нових соціальних умовах.

Аналіз основних досліджень і публікацій. У психолого-педагогічній літературі питання процесу соціалізації розглядаються в різних аспектах: у контексті розвитку i становлення особистості (Б. Ананьєв, О. Асмолов, Л. Божович, Л. Виготський, А. Петровський, К. Платонов, С. Рубінштейн, О. Мамічева, Л. Столяренко та ін.), визначення іiі сутності, механізмів, стадій, факторів впливу (В. Москаленко, А. Мудрик, Т. Шибутані та ін.), визначення особливостей ії прояву в дітей із вадами розвитку (Ю. Бистрова, В. Бондар, О. Глоба, В. Засенко, А. Колупаєва, В. Синьов, С. Синьова, І. Татьянчикова, О. Хохліна та ін.).

Формулювання цілей статті (постановка завдання). Мета статті визначити основні напрями оптимізації соціалізації дітей із психофізичними порушеннями на стадії ранньої трудової підготовки в умовах спеціальної загальноосвітньої школи.

Виклад основного матеріалу дослідження. Розгляд проблеми соціалізації передбачає визначення психолого-педагогічних основ забезпечення соціалізації дітей із вадами інтелектуального розвитку. Так, вивчення психологічного змісту предмета розгляду (соціалізації), його сутності, складових, стадій, механізмів, особливостей та закономірностей його прояву і становлення в дітей, показників ефективності впливів $є$ питаннями дослідження психологічного аспекту проблеми. Утім виявляється неоднозначним розуміння психологічного змісту, стадій, суті ключових питань і понять соціалізації. При аналізі поглядів учених різних напрямів (психологічного, загальнопедагогічного, соціологічного) на питання соціалізації спостерігається розмаїття їхніх теоретичних засад, підходів, широке коло тлумачень. Різні підходи до аналізу такого багатогранного процесу, як соціалізація, у якому діють 
складні соціальні, соціально-психологічні та інші механізми, мають рацію. Тому цілком правомірним $\epsilon$ існування різних визначень соціалізації, які відображають окремі аспекти цього процесу, виступаючи інструментами аналізу конкретних процесів формування особистості.

Визначають також й педагогічні основи забезпечення соціалізації. Соціалізація здійснюється засобами спеціально організованого педагогічного процесу - засобами організації, змісту, методики, визначеними відповідно до мети, предмета, очікуваних результатів (ефектів) соціалізації - розвивальних (особистісних надбань, розвитку інших складових психіки) та власне педагогічних (знань про норми діяння, способів діяльності, поведінки, спілкування). Зазначене є питаннями дослідження педагогічного аспекту проблеми.

Оскільки соціалізація розглядається як педагогічна проблема, основна роль у іiї забезпеченні відводиться навчальному закладу, передусім школі, яка $\epsilon$ основним інститутом соціалізації учнів і виконує основні функції: навчає дитину соціальних норм і зразків поведінки та контролює, наскільки глибоко i правильно засвоєні ці норми. При цьому цілі конкретної педагогічної ситуації повинні відображати загальні цілі, пов'язані з формуванням соціально активної особистості взагалі. Педагог і учні мають сприймати цілі діяльності як соціально значущі, спрямовані на формування в дітей активної, свідомої й самостійної позиції, поведінки в умовах конкретного суспільства. Підкреслюється, що при визначенні проблеми соціалізації і досягнення пї позитивних результатів, способи реалізації соціальних цілей з боку педагога мають розглядатися як методи навчання і виховання, а з боку учнів - як дії та операції, завдяки яким і досягаються ці цілі. Ось чому значна увага має приділятися саме оптимальному добору методів організації діяльності дітей.

Найважливішою метою шкільного навчання $\epsilon$ створення умов для подальшої соціалізації учнів. Сам процес навчання, спрямований на формування особистості дитини, вже створює передумови для іiі соціалізації. Провідна функція школи виявляється в тому, що вона своєю дією задає головний напрям і зміст соціалізаційних впливів, їхню орієнтацію, їхнє прочитання в контексті цілеспрямованої педагогічної дії. Етапи шкільної соціалізації є хронологічно послідовними складовими цілісного і багатовимірного педагогічного процесу.

При цьому, на думку Н. Лавриченко, конкретизація змісту роботи, спрямованої на реалізацію завдань різних етапів шкільної соціалізації, має знаходити своє відображення у відповідних педагогічних програмах. 
Необхідною умовою забезпечення соціалізації виступає спеціально організований процес навчання, а якість навчання у школі $\epsilon$ базою для успішного розв'язання низки проблем, пов'язаних із набуттям дітьми соціального досвіду. Значні можливості криються у процесі навчання загальноосвітніх предметів, які дають школярам певні знання та вміння, необхідні для самостійного життя, формують культурні потреби, сприяють вихованню морально-етичних норм $\mathrm{i}$ засвоєнню правил поведінки, а, отже, впливають на процес соціалізації загалом (Лавриченко, 2000).

Важливим педагогічним фактором, який суттєво впливає на процес соціалізації, є професійно-трудова підготовка, яка здійснюється в школі. Підкреслюється, що ефективне відтворення трудових ресурсів $є$ першоосновою суспільної стабільності та добробуту. Так, Є. Головаха справедливо вважає, що професійна орієнтація учнів має бути органічно пов'язана з їхніми життєвими перспективами і ціннісними орієнтаціями, складати суттєву частину соціального самовизначення (Головаха, 1988). Вона забезпечується всією навчальновиховною роботою школи, підвищенням ролі продуктивної праці, зв'язком шкіл iз базовими підприємствами, організаціями тощо. Саме тому трудове самовизначення і подальше працевлаштування $є$ основою соціального зростання особистості.

Отже, соціалізація учнів із психофізичними порушеннями стає особливо значущою на стадії ранньої трудової підготовки (в умовах спеціальної школи діти проходять такі стадії соціалізації: адаптації, індивідуалізації, інтеграції, ранньої трудової підготовки). На перший план виходить орієнтування старшокласників щодо майбутньої професії відповідно до їхніх здібностей і можливостей, формування в них професійно важливих якостей і трудових умінь i навичок, спрямованих на підвищення успішності професійно-трудової підготовки, насамперед із професій, яких навчають у школі.

Утім у системі професійно-трудового навчання учнів із психофізичними порушеннями чітко простежуються протиріччя, які гальмують їхню подальшу професійну соціалізацію. Це протиріччя між:

- організацією шкільної професійно-трудової підготовки і сучасними соціально-економічними умовами в суспільстві, які утруднюють подальше працевлаштування випускників;

- підвищеними кваліфікаційними вимогами до підготовки спеціалістів i особливостями розумового і психофізичного розвитку учнів, які ускладнюють оволодіння ними, навіть доступними за своїми можливостями, професіями; 
- обмеженою кількістю професій, за якими можуть бути працевлаштовані випускники зазначеної категорії, і ще меншою їх кількістю, за якою можна здійснювати професійно-трудову підготовку в умовах спеціальної загальноосвітньої школи.

Невирішеність зазначених протиріч ускладнює професійне орієнтування учнів і провокує суттєві труднощі, на які передусім мають звернути увагу педагоги: нестійкі професійні інтереси, їхня зміна; випадкові мотиви визначення професії; відсутність аналізу своїх можливостей при визначенні майбутньої професії, невпевненість у своїх силах; слабкі, незрілі уявлення про особливості та зміст профілю професійно-трудового навчання і професії, якої навчають у школі. Виявлено, що зазначені труднощі обумовлюються недостатньою корекційно-розвивальною роботою, передусім на стадії ранньої трудової підготовки в умовах спеціальної загальноосвітньої школи, що потребує ії посилення й удосконалення.

Спеціальний педагогічний вплив на стадії ранньої трудової підготовки передбачає роботу за основними змістовими лініями: орієнтування дитини щодо майбутньої професії (професії, якої навчають у школі); підвищення ефективності професійно-трудової діяльності учнів на основі врахування і розвитку їхніх можливостей та професійно важливих якостей.

При цьому особливої уваги потребує посилення профорієнтаційної роботи, яка здійснюється в школі. Профорієнтаційний процес повинен включати такі напрями:

- професійна діагностика учнів із подальшим аналізом їхніх нахилів, здібностей, особливостей і можливостей щодо обрання професій, які пропонує спеціальна школа. Ця робота має здійснюватись у контексті добору для учнів профілів професійно-трудового навчання на стадії індивідуалізації;

- підвищення рівня мотивації учнів до визначення професій, яких навчають у школі, формування до них позитивного ставлення. Ця робота має здійснюватись через опанування учнями визначених профілів на стадії інтеграції;

- отримання більш повної та якісної інформації про ринок праці, особливості працевлаштування, професійні вимоги щодо можливостей i здібностей школярів, шляхи підвищення успішності їхньої професійно-трудової діяльності, визначення перспектив професійного зростання старшокласників, набуття досвіду виробничої практики через взаємодію 3 професійними навчальними закладами. Ця робота повинна здійснюватись на стадії ранньої 
трудової підготовки.

При цьому особливого значення набуває всебічне вивчення учня, визначення його властивостей, які мають відповідати вимогам певної професії. Встановлення цієї відповідності здійснюється лише за умови систематичного i довготривалого вивчення кожного школяра 3 метою його професійного орієнтування. Педагогам потрібно мати уявлення про загальні основи профорієнтаційної роботи в спеціальному навчальному закладі, володіти методами діагностики особливостей дитини, розумітися на вікових етапах розвитку особистості. При визначенні професії для учня повинні враховуватися всі підструктури особистості: її спрямованість, здібності, характер, темперамент. Лише на основі нахилів учня, здібностей, позитивних якостей характеру вчитель може робити висновки щодо адекватності професійного визначення школярем.

Для підвищення ефективності профорієнтації старшокласників необхідно поєднувати їхню навчальну роботу зі спеціально організованими цілеспрямованими позакласними заходами. Так, доцільно проводити зустрічі 3 працівниками підприємств, представниками робітничих професій (наприклад, малярної, столярної, слюсарної, швейної справи) для надання розумово відсталим учням можливості поспілкуватися 3 ними. Необхідним є також розширення та вдосконалення професійних знань учнів у галузі виробничої сфери: ознайомлення 3 технічними засобами виробництва, особливостями трудових операцій і поведінкою робітника, користю і важливістю професії для суспільства, попитом і перспективами на ринку праці, а також моральним i матеріальним стимулом. У цьому зв'язку проводяться й диспути за участю представників робітничих професій, спеціалістів професійно-трудових ліцеїв, учителів професійно-трудової підготовки і батьків учнів для визначення розуміння учнями значущості професійних знань для самореалізації в професії.

Особливу увагу необхідно звертати на організацію зустрічей із представниками професійно-трудових навчальних закладів. Це стосується передусім дітей, які не бачать себе у професії, якої навчають у школі. Слід зазначити, що цей напрям профорієнтаційної роботи потребує суттєвого перегляду і посилення. Необхідно проводити інформування старшокласників про професійні заклади освіти, які знаходяться в найближчому до школи оточенні та мають відповідний профіль трудового навчання.

Доцільним $є$ врахування виробничих потреб регіону, попиту на ринку праці з тим, щоб спрямувати дітей на набуття подальшої професійної освіти за межами спеціальної школи. Для цього учням потрібно дати інформацію про 
навчальний заклад: визначення профілів його професійного навчання; освітній процес; виховні, розважальні та спортивні заходи; надання стипендії (матеріальної допомоги) та умови проживання; перспективи працевлаштування i професійного зростання, підвищення кваліфікації. У межах цієї програми можуть бути передбачені й відвідування учнями «Дня відкритих дверей» у професійно-трудовому ліцеї, а також проведення занять в умовах виробничої діяльності на базі цього закладу. Це сприятиме підвищенню якості та рівня професійно-трудової підготовки старшокласників, переорієнтуванню випускників на подальше навчання і підвищення своєї кваліфікації.

Можуть бути рекомендовані також цикли лекцій, місячники 3 профорієнтації, метою яких є ознайомлення учнів з провідними робітничими професіями транспорту, сфери побуту, торгівлі, сільського господарства. Роботу щодо професійного орієнтування учнів можна проводити відповідно до запропонованої нами програми (Татьянчикова, 2015).

Професійне навчання в спеціальній школі розглядається як процес управління діяльністю школярів по оволодінню ними певними професійними трудовими знаннями, трудовими уміннями й навичками, розвитку професійно важливих якостей. 3 огляду на це професійно-трудова діяльність повинна бути спрямована також на підвищення показників їі успішності, розширення сфери суспільно-корисної практичної діяльності школярів. Необхідним стає виготовлення продукції, яка має суспільно-корисне значення, що $є$ основою мотивації учнів до певного виду професійної діяльності й виникнення бажання підвищувати свою професійну успішність.

Доцільним стає врахування досвіду роботи кращих педагогів спеціальних шкіл. Можна запропонувати й проведення певних акцій, під час яких в учнів підвищується інтерес до суспільно-корисної праці, удосконалюються вміння і навички, які учні отримали 3 професій, яких навчають у школі. Так, акція «Допоможемо школі» передбачає: за столярною справою - полагодження шкільних меблів; за малярною справою - естетичне оформлення ігрових кімнат; за швейною справою - виготовлення серветок і фартухів для їдальні, пов'язок для чергових; за квітникарською справою - пересаджування, удобрювання i полив квітів; за слюсарною справою - перевірка сантехніки, полагодження кранів.

Акція «Допоможемо молодшим школярам» може проводитися за напрямами: «Усе сяє» - генеральне прибирання класної кімнати; «Будь охайним» - ремонт одягу, приведення його в порядок; «Приємно вчитися» - 
перевірка і полагодження шкільного приладдя; «Все в порядку» - огляд i приведення в порядок робочого місця (ремонт столів, стільців тощо); «Скоро свято» - підготовка до свята (пошив елементів одягу, костюмів, бантів для дівчаток тощо); «Посміхнись» - виготовлення у подарунок для дітей м'яких іграшок, картин, різних виробів і прикрас. Роботу можна проводити відповідно до запропонованої нами програми (Татьянчикова, 2017).

Результати дослідження. Результати опитування учнів показали, що відносно своєї майбутньої професійної діяльності зорієнтована лише половина 3 них. У школі здійснюється не професійне орієнтування, а формується здебільшого певне ставлення (позитивне або негативне) до обраної професії, на яке суттєво впливають сучасні погляди навколишніх і нові соціально-економічні умови. Уявлення ж старшокласників та їхніх батьків щодо престижності тих чи тих сфер майбутньої професійної діяльності практично тотожні. Визначаючи престижність сучасних професій, ними щонайперше називаються фінансова та банківська справа (хоча ці професії не попадають у коло тих, які можуть опанувати учні з вадами інтелектуального розвитку), а також професії бізнесу (хоча поняття «бізнес» діти цієї категорії трактують однобічно - передусім як засіб заробляння великих грошей). Виявлено, що учні хочуть працювати за професіями, які уможливлюють отримання високої заробітної платні або задоволення певних особистих професійних очікувань і життєвих потреб.

Крім того, дослідження показало, що 56,67\% школярів із психофізичними порушеннями не бажають у майбутньому працювати за професією, якої вони навчаються. Коло «бажаних» ними професій вузьке, знання про наявні види праці та їхню доступність у випускників неконкретні та недостатні («Буду працювати хоч де» - Іван Д., «Там, де більше платять» - Максим Г., «Будь-яким робітником на заводі»-Семен 3.). Серед професій називаються й ті, що не відповідають їхнім можливостям: водій теплохода, лікар, учитель, охоронець тощо. При цьому 13,33\% учнів не могли визначитися щодо жодної сфери праці. Однією з причин такого стану $є$ неадекватність реальних можливостей дітей, насамперед здібностей і нахилів, із вимогами професій, у тому числі й тих, яких навчають у школі, та недостатне розуміння і врахування цього учнями. Як показало дослідження, 61,67\% учнів співставляють свої можливості, насамперед здібності, із професією, якої навчають у школі. Утім залишається достатньо значною кількість школярів (38,33\%), яка цього не враховує.

Висновки. Отже, забезпечення соціалізації школярів 3 обмеженими психофізичними можливостями в процесі професійної підготовки в 
спеціальному навчальному закладі повинне виходити на розв'язання таких ключових питань: необхідно розширювати перелік спеціальностей, навчання яких здійснюється в школі, з урахуванням сучасних соціально-економічних змін у суспільстві; потрібно знайомити учнів із професіями, які їм доступні, визначати їх відповідно до своїх індивідуальних особливостей і можливостей; здійснювати професійне орієнтування школярів щодо професій з урахуванням їхнього змісту, видів праці, основних дій та вимог, які висуваються до кожної 3 них; підвищувати рівень професійно-трудової підготовки в спеціальному навчальному закладі (необхідним $є$ наявність сучасних майстерень, сировини для роботи, а також наближення навчальних занять до умов виробничої діяльності); рівень успішності професійної діяльності школярів (спрямовувати їх на суспільно корисну працю, виготовлення соціально значущої продукції).

\section{СПИСОК ВИКОРИСТАНИХ ДЖЕРЕЛ}

1. Головаха, Е. И. (1988). Жизненная перспектива и социальное самоопределение молодежи. Київ, Україна: Наук. думка.

2. Жулковска, Т. (2001). Социализация людей с ограниченныли интеллектуальными возможностями. Москва, Российская федерация: Московская гуманитарно-социальная академия.

3. Кравченко, Т. В. (2009). Соціалізація дітей шкільного віку у взаємодї сім'ї і школи: монографія. Київ, Україна: Інститут проблем виховання АПН України.

4. Лавриченко, Н. М. (2000). Педагогіка соціалізації. Європейські абриси. Київ, Україна: ВіРА ІНСАЙТ.

5. Мамічева, О.В. (2017). Метод проектів як засіб розвитку життєвої компетентності дітей з порушеннями інтелектуального розвитку. Слов'янськ, Україна: Зб. наук. праць, 1(81), 183-193.

6. Татьянчикова, I. В. (2015). Сочіалізація дітей з порушеннями інтелектуального розвитку: монографія. Слов'янськ, Україна: Вид-во Б. І. Маторіна.

7. Татьянчикова, I. В. (2017). Соціалізація дитини з вадами розвитку: теорія, досвід, технології: монографія. Слов'янськ, Україна: Вид-во Б. І. Маторіна.

\section{PSYCHOLOGICAL AND PEDAGOGICAL DIRECTIONS OF SOCIALISATION OF CHILDREN WITH PSYCHOPHYSICAL DISORDERS IN THE PROCESS OF VOCATIONAL TRAINING}

\section{Olena Mamicheva}

Doctor of Psychological Sciences, Professor, the Dean of the Faculty of Special Education SHEI "Donbas State Pedagogical University"

Sloviansk, Ukraine

ORCID ID 0000-0001-5299-7939

lena_sk_74@ukr.net 
Психолого-педагогічні напрями оптимізації соціалізації дітей із психофізичними порушеннями в процесі професійної підготовки

\title{
Iryna Tatianchykova
}

Doctor of Pedagogical Sciences, Professor, the Head of the Department of Special Education and Inclusion

SHEI "Donbas State Pedagogical University"

Sloviansk, Ukraine

ORCID ID 0000-0002-9526-9672

i.tatyanchikova@gmail.com

\begin{abstract}
The article presents the consideration of the issue of socializing, defining psychological and pedagogical bases of ensuring the socialization of children with psychophysical disorders, studying the psychological content of the subject matter, its essence, components, stages, mechanisms, features and regularities of its manifestation and development. The main content lines of conducting corrective and developmental actions are revealed at the present stage, as well as the issues, which contribute to providing the pupils' socialization in the process of vocational training in special education institution, are covered. The conditions for developing the society are defined which are the important issues of preparing children with psychophysical disorders for the independent life that includes mastering not only knowledge and skills, but also skills to solve certain life problems, to adapt to the difficult life conditions, and to adequately navigate the society.

It is clarified that pupils' socialization gets more significance at the stage of early vocational training that is why the career guidance of senior pupils comes to the fore according to their skills and abilities, as well as the development of professionally important qualities that are oriented for increasing the efficiency of vocational training. The authors pay special attention to the issue of vocational education in the context of managing pupils' learning activities for mastering the knowledge and skills, developing professionally important qualities. The main disadvantages are pointed out and the guidelines for improving the vocational training of the pupils with psychophysical disorders are proposed. The authors reveal the key issues that contribute to providing the socialization of children in the process of their vocational training in special education institution: the extension of the list of specialties which are trained at school; the implementation of pupils' vocational guidelines, taking into account the content, work activities, and demands that are made for each of them; the improvement of pupils' vocational training in special education institutions.
\end{abstract}

\section{REFERENCES}

1. Holovakha, E. I. (1988). Life outlook and social self-determination of youth.. Kyiv, Ukraine: Naukova dumka.

2. Zhulkovska, T. (2001). Socialization of people with intellectual disabilities. Moscow, the Russian Federation: Moskovskaya gumanitarno-sotsialnaya akademiya.

3. Kravchenko, T. V. (2009). School children's socialisation in the interaction of family and school: a monograph. Kyiv, Ukraine: Institut problem vikhovanni APN Ukrayini.

4. Lavrychenko, N. M. (2000). Pedagogy of socialisation. European patterns. Kyiv, Ukraine: ViRA INSAIT.

5. Mamicheva, O. V. (2017). Method of design for development of competency of children with impaired development of technology. Sloviansk, Ukraine: Zb. nauk. prats, 1(81), 183-193.

6. Tatianchykova, I. V. (2015). Socialization of children with impaired intellectual development. Sloviansk, Ukraine: Vid-vo B. I. Matorina.

7. Tatianchykova, I. V. (2017). Socialization of the child with developmental disabilities: theory, experience, technologies: monograph. Sloviansk, Ukraine: Vid-vo B. I. Matorina, 2017.

Матеріали надійшли до редакції 17.09.2019 р. 